\title{
Hvor mye av sykefraværet er arbeidsrelatert?
}

\author{
Sammendrag \\ Bakgrunn. Sykefravær er et aktuelt \\ tema, blant annet etter revisjonen av \\ intensjonsavtalen om et mer inklude- \\ rende arbeidsliv (IA-avtalen). I hvilken \\ grad sykefravær kan ha sammenheng \\ med arbeid, har likevel vært lite omtalt.
}

Materiale og metode. Artikkelen bygger på et ikke-systematisk litteraturs $ø$ k i PubMed og egen forskning og erfaring.

Resultater. Forskjellige studier tyder på at en vesentlig del av sykefraværet kan skyldes sykdom forårsaket av arbeidsforhold. Tungt fysisk arbeid, belastende arbeidsstillinger og lav kontroll over arbeidssituasjonen er faktorer som er spesielt viktige. Personer med arbeidsrelatert sykdom har større behov for fravær fra jobben enn personer med tilsvarende sykdom som ikke skyldes arbeidet. Tiltak på arbeidsplassen som forebygger arbeidsrelatert sykdom, kan forebygge sykefravær. Sykefravær som skyldes ubalanse mellom individuelle ressurser og jobbkrav, kan ofte forebygges eller forkortes ved tiltak på arbeidsplassen, uansett hva som er årsaken til denne ubalansen.

Fortolkning. Jeg mener at man bør legge mer vekt på primærforebyggende tiltak for å redusere arbeidsrelatert sykdom og tilrettelegge arbeidet for personer med økt risiko for sykefravær, men dette er ikke tilstrekkelig ivaretatt i dagens IA-avtale.
Ingrid Sivesind Mehlum

ism@stami.no

Avdeling for arbeidsmedisin og epidemiologi

Statens arbeidsmiljøinstitutt

Postboks 8149 Dep

0033 Oslo

Sykefravær er et aktuelt tema i forbindelse med revisjonen av intensjonsavtalen om et mer inkluderende arbeidsliv (IA-avtalen) i $2010(1,2)$. I hvilken grad sykefraværet kan ha sammenheng med arbeid, har vært lite diskutert, men kan ha stor betydning for hvilke tiltak som vil være effektive når det gjelder å redusere sykefravær og utstøting. Hittil har man i IA-avtalen først og fremst konsentrert seg om å redusere sykefravær gjennom tiltak for å få sykmeldte tilbake i arbeid (sekundærforebygging), fremfor tiltak for å hindre at arbeidstakere faller ut av arbeidet (primærforebygging) (3). Ekspertgruppen som ble oppnevnt av Arbeidsdepartementet for å vurdere mulige administrative tiltak for å redusere sykefraværet, foreslo knapt noen tiltak av primærforebyggende art i sin rapport (4).

I denne artikkelen gir jeg en oversikt over i hvor stor grad sykefraværet kan være arbeidsrelatert, dvs. ha sammenheng med arbeid og forhold på arbeidsplassen.

\section{Materiale og metode}

Grunnlaget for artikkelen er et ikke-systematisk litteratursøk i PubMed med et skjønnsmessig utvalg av artikler, basert på mine kunnskaper innen feltet og erfaringer fra egne studier.

\section{Hva innebærer begrepet «arbeidsrelatert»?}

Alt sykefravær kan sies å være arbeidsrelatert i den forstand at man har problemer med å utføre arbeidet pga. sykdom, dvs. «helserelaterte arbeidsproblemer». Men dette er en lite hensiktsmessig definisjon med tanke på å forebygge på arbeidsplassen. «Arbeidsrelaterte helseproblemer» definerer man ofte som helseproblemer (sykdommer og skader) som helt eller delvis forårsakes eller forverres av arbeidsforhold (5-7). Tiltak på arbeidsplassen vil kunne forebygge eller redusere slike helseproblemer og sykefravær forårsaket av helseproblemene.

\section{Har sykdom}

\section{sammenheng med arbeid?}

> Se også side 109 rede omkring år 1700 omtalte den italienske legen Ramazzini spesifikke yrkessykdommer knyttet til mer enn 50 yrker (8). I Finland er det beregnet at $7 \%$ av dødsfall i relevante sykdoms- og alderskategorier kan tilskrives arbeidsfaktorer, høyere blant menn (10\%) enn blant kvinner ( $2 \%)$, og totalt $4 \%$ av alle dødsfall uansett alder og diagnose (9). Det er beregnet at om lag $20 \%$ av lungekrefttilfeller blant norske menn ville vært unngått uten yrkeseksponering $(10,11)$. Det samme gjelder $85 \%$ av alle mesoteliomer, en kreftform som hovedsakelig er forårsaket av asbesteksponering $\mathrm{i}$ arbeid, og $32 \%$ av tilfeller med nese- og bihulekreft (10). American Thoracic Society anslår, basert på epidemiologisk litteratur, at om lag $15 \%$ av astmatilfeller blant voksne og $15 \%$ av kols (kronisk obstruktiv lungesykdom)-tilfeller i befolkningen kan tilskrives arbeid (12).

Arbeidsrelaterte helseproblemer er svært vanlige. Ved helseundersøkelsen i Oslo (HUBRO-studien) rapporterte ca. $60 \%$ at de hadde hatt helseproblemer som skyldtes arbeidsforhold den siste måneden (13). Vanligst var nakke- og skuldersmerter og korsryggsmerter, som ble tilskrevet arbeidet av henholdsvis tre av fire og halvparten med slike smerter. Tallene omfatter alle grader av helseproblemer, og personer med lette symptomer vil sannsynligvis sjelden være sykmeldt. Blant yrkesaktive som rapporterte arbeidsrelaterte muskel- og skjelettsmerter ved Statistisk sentralbyrås levekårsundersøkelse i 2006 var ca. $15 \%$ «svært plaget» og $25 \%$ «ganske plaget» av smertene, mens for psykiske symptomer var andelen henholdsvis $7 \%$ og $20 \%$.

Arbeidsrelaterte helseproblemer er også en hyppig årsak til at folk oppsøker lege. I en studie blant yrkesaktive pasienter i allmennpraksis fant Hilt og medarbeidere at $40 \%$ av kvinnene og $54 \%$ av mennene mente at deres helseproblem hadde mulig eller sikker

\section{Hovedbudskap}

- En vesentlig del av sykefraværet har sammenheng med arbeidsforhold

- Tiltak på arbeidsplassen kan forebygge arbeidsrelatert sykdom og sykefravær

- Tiltak på arbeidsplassen kan også redusere sykefravær som skyldes ubalanse mellom individuelle ressurser og jobbkrav 
årsakssammenheng med arbeid (14). I to nordiske studier, basert på allmennlegers vurdering, var ca. én av fem konsultasjoner sannsynlig eller mulig arbeidsrelatert, med en enda høyere andel (mellom $1 / 3$ og $1 / 2$ ) for muskel- og skjelettlidelser $(15,16)$. De legevurderte anslagene kan ha vært for lave. I 2006 sendte bare $7 \%$ av norske allmennleger melding om arbeidsrelatert sykdom til Arbeidstilsynet (17), noe som kan tyde på at mange leger er lite oppmerksomme på sykdommers sammenheng med arbeid.

\section{Har sykefravær}

\section{sammenheng med arbeid?}

Figur 1 viser en enkel modell for sammenhengen mellom arbeid og sykefravær. Arbeidsforhold kan ha betydning, både gjennom skadelig påvirkning av helsen og gjennom de kravene som stilles i arbeidet. Behovet for sykefravær vil være avhengig av interaksjonen mellom den enkeltes helse og jobbkravene (18). Samme sykdom eller funksjonsnedsettelse vil derfor kunne gi ulike grader av arbeidsuførhet pga. ulike jobbkrav (19).

Arbeid kan også ha betydning for sykefravær via psykologiske og sosiale mekanismer, som bl.a. kan påvirke motivasjon. Disse er ikke inkludert i denne enkle modellen og vil ikke bli omtalt videre i artikkelen, selv om de vil være viktige i en mer omfattende biopsykososial modell (20). I tillegg er individfaktorer, som alder, kjønn og personlighet, av betydning.

\section{Selvrapportert arbeidsrelatert sykefravær}

Blant alle yrkesaktive i levekårsundersøkelsen i 2006 rapporterte $18 \%$ å ha hatt minst ett sammenhengende sykefravær på mer enn 14 dager de siste 12 månedene. Av disse svarte ca. $40 \%$ at årsaken til fraværet var helseproblemer som helt eller delvis skyldtes jobben (21). Dette utgjør $7 \%$ av de yrkesaktive, noe høyere blant kvinner ( $8 \%$ ) enn blant menn (5\%). Tilsvarende tall (7\% av yrkesaktive) ble også funnet ved en senere undersøkelse om arbeidsrelaterte sykdommer og skader knyttet til Statistisk sentralbyrås arbeidskraftundersøkelse i 2007, med bruk av litt andre spørsmål (22). Tallene varierte sterkt med yrke, fra under $1 \%$ blant universitetsutdannet helsepersonell til $13 \%$ blant renholdere, næringsmiddelarbeidere, kokker og kjøkkenassistenter. Andelen av sykefraværet som ble rapportert som arbeidsrelatert, varierte også betydelig, fra $5 \%$ til $50 \%$ for nevnte yrkesgrupper (21).

Ved en undersøkelse av sykefravær blant 118 allmennleger og deres pasienter i Buskerud fant Tellnes og medarbeidere at tungt fysisk arbeid ble vurdert av lege og/eller pasient å være medvirkende årsak til sykmeldingen hos $48 \%$ av pasientene (23). Den arbeidsrelaterte andelen var betydelig høyere hos pasienter med muskel- og skjelettlidelser $(78 \%)$, spesielt dersom de hadde tungt fysisk arbeid eller gikk og sto mye

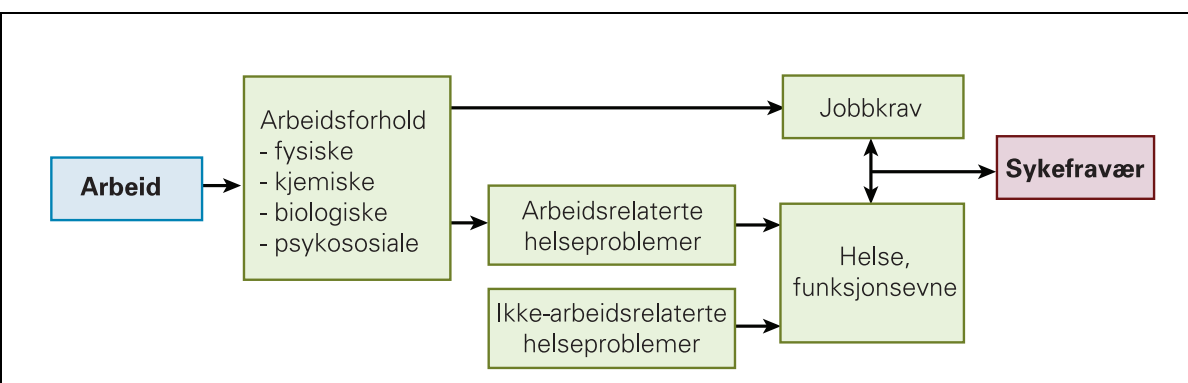

Figur 1 Enkel modell for sammenheng mellom arbeid og sykefravær

i jobben (over 90\%). Psykiske faktorer i arbeidet ble vurdert å være medvirkende årsak til sykmeldingen hos $32 \%$. Det var store variasjoner med type helseproblem og type arbeid.

\section{Kan vi stole på selvrapportering?}

Spørreskjemaer blir ofte brukt når man undersøker arbeidsrelaterte helseproblemer, blant annet blir det gjort i levekårsundersøkelsene og i de europeiske arbeidsmiljøundersøkelsene (24). Mange er skeptiske til slik selvrapportering og mener personene selv vil overvurdere sammenhengen med arbeidet. I HUBRO-studien ble selvrapportering sammenliknet med legevurdering for 217 personer med smerter i nakke/skulder eller arm (25). Legene brukte kriterier utarbeidet av en europeisk ekspertgruppe for å vurdere om smertene kunne være forårsaket av arbeidsforhold (26). Smertene ble noe hyppigere vurdert å være arbeidsrelatert av personene selv enn av legene: 80 mot $65 \%$ for nakke- og skuldersmerter og 78 mot $72 \%$ for armsmerter. Selvrapportering ser dermed ut til å gi et rimelig godt mål på hvor stor andel av helseproblemene som er arbeidsrelatert, men dette vil kunne variere med type helseproblem og kriterier for vurdering av arbeidsrelasjonen (25).

\section{Arbeidsrelatert sykdom og arbeidsevne}

Mye tyder på at personer med arbeidsrelaterte helseproblemer i større grad blir sykmeldt enn personer med tilsvarende helseproblemer av andre årsaker. En person som blir syk på grunn av jobben, vil naturlig nok ha større behov for å være borte fra den jobben som gjør vedkommende syk. I en undersøkelse blant personer sykmeldt for astma i mer enn 16 dager, fant Leira og medarbeidere at hele $70 \%$ var arbeidsrelatert, basert på rapportering av luftveisplager i forbindelse med arbeidet og bedring ved fravær fra arbeidet (27). Dette er vesentlig høyere enn i befolkningen generelt, bl.a. i HUBRO-studien, der $18 \%$ av personer med astmasymptomer mente at symptomene skyldtes jobb (13). I en finsk studie var risikoen for full arbeidsuførhet nesten 13 ganger høyere blant pasienter som rapporterte arbeidsrelaterte helseproblemer, sammenliknet med dem som rapporterte ikke-arbeidsrelaterte helseproblemer (28).

\section{Betydningen av arbeidsmiljøfaktorer}

En rekke arbeidsrelaterte faktorer har vært studert i relasjon til sykefravær, spesielt fysiske/ergonomiske forhold, slik som tungt fysisk arbeid, belastende arbeidsstillinger og repetitivt arbeid, psykososiale forhold, slik som psykologiske jobbkrav, jobbkontroll og sosial støtte på arbeidsplassen, og organisatoriske forhold, slik som skiftarbeid. I et omfattende oversiktsarbeid om årsaker til sykefravær fra 2004 (29) fant man begrenset vitenskapelig dokumentasjon for at fysiske arbeidsforhold, spesielt tungt fysisk arbeid, kunne forårsake sykefravær, og moderat dokumentasjon for en årsakssammenheng med lav kontroll over arbeidssituasjonen (30). For sykefravær med ryggdiagnoser fant man imidlertid at flere faktorer hadde betydning, bl.a. lav jobbtilfredshet (moderat dokumentasjon), lav jobbkontroll og arbeid med tunge løft eller med bøyd eller vridd rygg (begrenset dokumentasjon) (31). Til tross for svært mange studier og godt dokumentert statistisk sammenheng mellom arbeidsforhold og sykefravær, konkluderte man likevel med at den vitenskapelige dokumentasjonen for en årsakssammenheng stort sett var begrenset, spesielt på grunn av mulig seleksjon eller konfundering (confounding) (30). Selv om sammenhengen mellom visse arbeidsforhold og sykdom er godt dokumentert, vil de fleste med sykdommen vanligvis ikke være sykmeldt, noe som kan bidra til relativt svak dokumentasjon (32).

I Danmark er det utført en rekke longitudinelle studier der de har søkt å redusere svakheter ved tidligere forskning (33). I studiene har de kombinert bruken av spørreskjemadata og registerdata, og de har studert faktorer av betydning for ulike faser av et sykefraværsforløp (34).

De beregnet at antall personer med et årlig sykefravær utover seks dager kunne vært $40 \%$ lavere hvis alle hadde hatt et like godt fysisk og psykisk arbeidsmiljø som de $10 \%$ lavest eksponerte (35). I andre studier fra Danmark har man funnet tilsvarende tall (36). Tungt fysisk arbeid, slik som løfte/ bære eller skyve/trekke tungt, og belastende arbeidsstillinger, slik som arbeid stående/på 
huk eller med bøyd/vridd nakke/rygg, ser ut til å ha spesielt stor betydning (37). Flere psykososiale jobbfaktorer synes å være viktige, deriblant jobbkontroll (selvbestemmelse i arbeidet), sosial støtte fra leder, psykologiske jobbkrav, forutsigbarhet og rollekonflikter $(33,38)$. Resultatene varierer noe fra studie til studie, og mellom kvinner og menn, spesielt når det gjelder psykososiale faktorer (33). Tilskrivbar andel av sykefraværet ble funnet å være høyere for arbeidsrelaterte faktorer enn for livsstilsfaktorer, for eksempel røyking (26\% blant kvinner og $17 \%$ blant menn) (39).

Sosiale ulikheter i helse er godt dokumentert, og arbeidsforhold er vist å ha betydning for slike ulikheter (40). I en dansk studie fant man at fysiske og psykososiale arbeidsmiljøfaktorer kunne forklare hele $40-50 \%$ av forskjellene i langtidssykefravær mellom høyeste og laveste sosiale klasse (henholdsvis ledere/ akademikere og faglærte/ufaglærte arbeidere), justert for bl.a. livsstilsfaktorer (41).

\section{Betydningen av strukturelle arbeidsforhold}

I flere studier har man vist at strukturelle forhold, slik som omorganisering og nedbemanning, kan medføre høyere sykefravær, økt tendens til uførepensjonering og høyere dødelighet i de påfølgende årene (42-46). Dette gjelder både blant dem som selv rammes $(42,43)$, og blant dem som blir igjen $i$ bedriften etter en nedbemanning $(43,46)$. Økte jobbkrav, lavere jobbkontroll og økt jobbusikkerhet ved nedbemanning er vist å ha betydning for helse og sykefravær (47). I prosjektet «Den nye staten» fant man at sykefraværsøkningen i Posten og i Vegvesenet/Mesta, etter nedbemanningen fra midten av 1990-årene, langt på vei kunne forklares av lengre sykefraværsvarighet (44). Andre studier har imidlertid vist uforandret eller lavere sykefravær etter nedbemanning $(48,49)$, noe som er blitt tolket som et uttrykk for «sykenærvær», dvs. at man går på jobb selv om man er syk, spesielt personer i tidsbegrenset stilling og med lavere jobbsikkerhet $(46,48)$.

\section{Forebygging}

\section{av arbeidsrelatert sykefravær}

Arbeidsuførhet er et relasjonelt begrep, og man må se det i forhold til den enkeltes ressurser og de kravene som stilles i arbeidet (18). Dersom det blir et misforhold mellom personens funksjonsnivå og jobbkravene, vil dette kunne føre til problemer med å utføre arbeidet og dermed behov for sykmelding (50). En slik ubalanse kan oppstå ved sykdom og nedsatt helse med uforandrede jobbkrav, men kan også utvikle seg ved opprettholdt helse og funksjonsevne dersom jobbkravene øker, f.eks. i forbindelse med omorganisering eller nedbemanning (18). Ofte vil det være kombinasjoner av disse to variantene.

Tiltak på arbeidsplassen som forebygger arbeidsrelatert sykdom, vil kunne forebygge sykefravær. I tillegg vil sykefravær som skyl- des ubalanse mellom individuelle ressurser og jobbkrav, ofte kunne forebygges eller forkortes ved tiltak på arbeidsplassen, uansett hva som primært er årsak til ubalansen. Dette vil kunne gjelde de fleste tilfellene av sykefravær, som i så måte kan sies å være arbeidsrelatert i vid forstand. Det vil omfatte «jobbrelatert funksjonsfravær», men også i stor grad «relativt funksjonsfravær» i Bruusgaard $\&$ Claussens inndeling av sykefravær (51).

Foreløpig finnes det relativt begrenset dokumentasjon om effekten av arbeidsplasstiltak på sykefravær. I en nylig publisert Cochrane-oversikt, basert på seks randomiserte kontrollerte studier, konkluderte man med at det var moderat vitenskapelig dokumentasjon for at intervensjoner på arbeidsplassen kunne redusere sykefravær ved muskel- og skjelettlidelser, sammenliknet med vanlig oppfølging (52). Nyere randomiserte intervensjonsundersøkelser har vist at screening av ansatte med arbeidsmedisinsk funksjonsvurdering og påfølgende intervensjon overfor personer med økt risiko for fravær, kan gi en fraværsreduksjon på $30-40 \%(53-55)$.

Arbeidsplasstiltak overfor gravide er vist å kunne redusere sykefravær under svangerskapet. I et prosjekt i Sør-Troms ble gjennomsnittlig sykefravær redusert fra ca. 16 til 2,4 uker $(85 \%)$, og bruken av gradert sykmelding $ø k t e(56)$. En studie basert på den norske mor og barn-undersøkelsen bekrefter betydningen av å tilrettelegge for gravide. Kristensen og medarbeidere fant at halvparten av gravide som hadde behov for tilrettelegging, men som ikke hadde fătt det, hadde mer enn to ukers fravær mellom uke 17 og 30 i svangerskapet, mens de som hadde fătt en slik ordning, hadde 11 prosentpoeng lavere risiko (57).

\section{Diskusjon}

Denne litteraturgjennomgangen viser at sykefravær i mange tilfeller er arbeidsrelatert, enten i snever forstand, når sykefraværet skyldes arbeidsrelatert sykdom eller skade, eller i videre betydning, når sykefraværet skyldes ubalanse mellom individuelle ressurser og jobbkrav. I begge tilfeller vil tiltak på arbeidsplassen kunne forebygge eller forkorte sykefravær.

Mange ressurser settes inn for å få sykmeldte tilbake i arbeid, både fra leger, arbeidsgivere og NAV. Man bør imidlertid legge mer vekt på primærforebyggende tiltak for å redusere arbeidsrelatert sykdom og tilrettelegge arbeidet for personer med $ø$ kt risiko for sykefravær før de blir sykmeldt. For mange vil det ta lang tid før de da er i stand til å arbeide igjen.

Arbeidsgiver har et klart ansvar, men ser ofte ikke behovet for tiltak før personen blir alvorlig syk eller sykmeldt. Legene kan se behovet, men mangler ofte kunnskap om arbeidsrelaterte forhold og kontakt med arbeidsgiver. Bedriftshelsetjenesten har både kunnskap om sammenhenger mellom arbeid og helse og kontakt med bedriftene.
Bedriftshelsetjenesten burde ha en sentral rolle $\mathrm{i}$ dette arbeidet, men er lite synlig $\mathrm{i}$ dagens IA-avtale og blir sannsynligvis for lite brukt av både behandlende leger, arbeidsgivere, arbeidstakere og NAV.

IA-avtalen har tre mål, men så langt har man konsentrert seg mest om å redusere sykefraværet. Tiltak som bidrar til at vi lykkes med å inkludere eldre og personer med redusert arbeidsevne, vil føre til at disse kan bli værende $\mathrm{i}$ arbeid, men ofte med noe høyere sykefravær. Det er kanskje likevel en lav pris å betale for å holde flest mulig i arbeid?

Jeg takker Helge Kjuus ved Statens arbeidsmiljøinstitutt for kommentarer til manuskriptet.

Oppgitte interessekonflikter: Ingen

\section{Litteratur}

1. Intensjonsavtale om et mer inkluderende arbeidsliv. Oslo: Arbeids- og administrasjonsdepartementet, 2001.

2. Intensjonsavtale om et mer inkluderende arbeidsliv 1. mars 2010-31. desember 2013 (IA-avtalen). Oslo: Arbeidsdepartementet, 2010.

3. Ose SO, Bjerkan AM, Pettersen I et al. Evaluering av IA-avtalen (2001-2009). SINTEF-rapport nr. A11947. Trondheim: SINTEF Teknologi og samfunn, 2009

4. Tiltak for reduksjon i sykefravær: Aktiviseringsog nærværsreform. Ekspertgrupperapport. Oslo: Arbeidsdepartementet, 2010

5. Verdens helseorganisasjon. Identification and control of work-related diseases. Rapport nr. 714 Genève: World Health Organization, 1985

6. Regulation (EC) No $1338 / 2008$ of the European Parliament and of the Council of 16 December 2008 on Community statistics on public health and health and safety at work. http://eur-lex. europa.eu/LexUriServ/LexUriServ.do?uri=0 J: L:2008:354:0070:01:EN:HTML (25.11.2010).

7. Regulations (Standards - 29 CFR). Recording and reporting occupational injuries and illnesses. Determination of work-relatedness. Part Number 1904.5. Washington, DC: Occupational Safety \& Health Administrations, 1972.

8. Ramazzini B. Diseases of Workers. Translated from the Latin text De Morbis Artificum of 1713 by Wilmer Cave Wright. New York, NY: Hafner Publishing Company, 1964

9. Nurminen M, Karjalainen A. Epidemiologic estimate of the proportion of fatalities related to occu pational factors in Finland. Scand J Work Environ Health $2001 ; 27: 161-213$.

10. Dreyer L, Andersen A, Pukkala E. Avoidable cancers in the Nordic countries. Occupation. APMIS Suppl 1997; 76: 68-79.

11. Haldorsen T, Andersen A, Boffetta P. Smokingadjusted incidence of lung cancer by occupation among Norwegian men. Cancer Causes Control 2004: 15: 139-47.

12. Balmes J, Becklake M, Blanc P et al. American Thoracic Society Statement: Occupational contribution to the burden of airway disease. Am J Respir Crit Care Med 2003; 167: 787-97.

13. Mehlum IS, Kjuus H, Veiersted KB et al. Selfreported work-related health problems from the Oslo Health Study. Occup Med (Lond) 2006; 56 : $371-9$.

14. Hilt B, Kvenild K, Stenersen H. Arbeidsrelaterte sykdommer i allmennpraksis. Tidsskr Nor Lægeforen 2003; 123: 2065-7

15. Kibsgård KA, Andersen JH, Rasmussen K. Arbejdsmedicin i almen praksis. En undersøgelse af arbejdsskaders omfang og art i Ringkjøbing Amt. Ugeskr Læger 1998; 160: 4863-7.

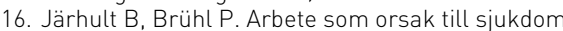
Läkartidningen 1986; 83: 3497-501.

17. Samant $Y$, Parker D, Wergeland E et al. The Norwegian Labour Inspectorate's Registry for WorkRelated Diseases: data from 2006. Int J Occup Environ Health 2008; 14: 272-9. 
18. Westin S. Ervervsmessig uførhet - et forhold mellom individets ressurser og arbeidslivets krav. I: Bruusgaard D, Hatland A, Syse A, red. Et nødvendig gode. Folketrygdens plass i velferdssamfunnet. Oslo: AdNotam Gyldendal, 1994: 133-46.

19. Stattin M. Retirement on grounds of ill health. Occup Environ Med 2005; 62: 135-40.

20. Knardahl S. Sykefravær har årsaker i individet, i virksomheten og i samfunnet. Oslo: Statens arbeidsmiljøinstitutt, 2010. www.stami.no/ ?nid=61605\&lcid=1044 (28.10.2010).

21. Tynes T, Eiken T, Grimsrud TK et al. Arbeidsmiljø og helse - slik norske yrkesaktive opplever det. Resultater fra Statistisk sentralbyrås levekårsundersøkelse for 2006. STAMI-rapport nr. 16/2008. Oslo: Statens arbeidsmiljøinstitutt, 2008.

22. Gravseth HM. Arbeidsskader og arbeidsrelaterte helseproblemer. STAMI-rapport nr. 4/2010. Oslo: Statens arbeidsmiljøinstitutt, 2010.

23. Tellnes G, Bruusgaard D, Sandvik L. Occupational factors in sickness certification. Scand J Prim Health Care 1990; 8: 37-44.

24. Parent-Thirion A, Fernández Macías E. Hurley J et al. Fourth European Working Conditions Survey. Dublin: European Foundation for the Improvement of Living and Working Conditions, 2007.

25. Mehlum IS, Veiersted KB, Wærsted M et al. Selfreported versus expert-assessed work-relatedness of pain in the neck, shoulder, and arm. Scand J Work Environ Health 2009; 35: 222-32.

26. Sluiter JK, Rest KM, Frings-Dresen MH. Criteria document for evaluating the work-relatedness of upper-extremity musculoskeletal disorders. Scand J Work Environ Health 2001; 27 (Suppl 1): $1-102$.

27. Leira HL, Berg JA, Bratt U et al. Mye arbeidsrelatert sykdom blant astmatikere. Tidsskr Nor Lægeforen 2006; 126: 2367-9

28. Martimo KP, Varonen H, Husman K et al. Factors associated with self-assessed work ability. Occup Med (Lond) 2007; 57: 380-2.

29. Alexanderson K, Norlund A, red. Sickness absence - causes, consequences, and practices. A systematic literature review by the Swedish Council on Technology Assessment in Health Care. Scand J Public Health Suppl 2004; 63.

30. Allebeck P, Mastekaasa A. Chapter 5. Risk factors for sick leave - general studies. Scand J Public Health Suppl 2004; 63: 49-108.

31. Hansson T, Jensen I. Chapter 6. Sickness absence due to back and neck disorders. Scand J Public Health Suppl 2004; 63: 109-51.

32. Alexanderson K, Norlund A. Chapter 1. Aim, back- ground, key concepts, regulations, and current statistics. Scand J Public Health Suppl 2004; 63 $12-30$.

33. Lund T, Labriola M. Sickness absence in Denmark - research, results and reflections. Scand J Work Environ Health 2009; 7: 5-14.

34. Labriola M. Conceptual framework of sickness absence and return to work, focusing on both the individual and the contextual level. Work 2008; 30 . 377-87.

35. Labriola M, Lund T, Burr H. Prospective study of physical and psychosocial risk factors for sickness absence. Occup Med (Lond) 2006; 56: 469-74.

36. Jensen $C$. Lund T, Mossing R et al. Arbejdsmiliø og fravær. København: Arbejdsmiljøinstituttet, 2002.

37. Bang Christensen K, Lund T, Labriola M et al. The fraction of long-term sickness absence attributable to work environmental factors: prospective results from the Danish Work Environment Cohort Study. Occup Environ Med 2007; 64: 487-9.

38. Nielsen ML, Rugulies R, Smith-Hansen L et al. Psychosocial work environment and registered absence from work: estimating the etiologic fraction. Am J Ind Med 2006; 49: 187-96.

39. Christensen KB, Lund T, Labriola M et al. The impact of health behaviour on long term sickness absence: results from DWECS/DREAM. Ind Health 2007; 45: 348-51.

40. Mehlum IS, Kristensen P, Kjuus H et al. Are occupational factors important determinants of socioeconomic inequalities in musculoskeletal pain? Scand J Work Environ Health 2008; 34: 250 -9

41. Christensen KB, Labriola M, Lund T et al. Explaining the social gradient in long-term sickness absence: a prospective study of Danish employees. J Epidemiol Community Health 2008; 62: 181-3.

42. Westin S, Norum D, Schlesselman JJ. Medical consequences of a factory closure: illness and disability in a four-year follow-up study. Int J Epidemiol 1988: 17: 153-61.

43. Fevang E, Røed K. Omstillinger og nedbemanninger blant pleiere - en belastning for folketrygden. Søkelys på arbeidsmarkedet 2005; 22: 233-42.

44. Trygstad S, Lorentzen T, Løken E et al. Den nye staten. Omfang og effekter av omstillingene i staten 1990-2004. Fafo-rapport 530. Oslo: Fafo, 2006.

45. Rege M, Telle K, Votruba M. The effect of plant downsizing on disability pension utilization. J Eur Econ Assoc 2009. 7: 754-85.

46. Vahtera J, Kivimäki M, Pentti J et al. Organisational downsizing, sickness absence, and mortality: 10-town prospective cohort study. BMJ 2004; 328 : 555

47. Kivimäki M, Vahtera J, Pentti J et al. Factors underlying the effect of organisational downsizing on health of employees: longitudinal cohort study. BMJ 2000; 320: $971-5$.

48. Theorell T, Oxenstierna G, Westerlund H et al. Downsizing of staff is associated with lowered medically certified sick leave in female employees. Occup Environ Med 2003; 60: E9.

49. Østhus S, Mastekaasa A. The impact of downsizing on remaining workers' sickness absence. Soc Sci Med 2010; 71: 1455-62.

50. Lindén V. Absence from work and work capacity. Bergen: Rikstrygdeverket, Bergen trygdekontor, 1967

51. Bruusgaard D, Claussen B. Ulike typer sykefravær. Tidsskr Nor Legeforen 2010; 130: 1834-6.

52. van Oostrom SH, Driessen MT, de Vet $\mathrm{HC}$ et al. Workplace interventions for preventing work disability. Cochrane Database Syst Rev 2009; nr.2: CD006955. doi: 10.1002/14651858.CD006955.pub2.

53. Kant I, Jansen NW, van Amelsvoort LG et al. Structured early consultation with the occupational physician reduces sickness absence among office workers at high risk for long-term sickness absence: a randomized controlled trial. J Occup Rehabil 2008; 18: 79-86

54. Taimela S, Malmivaara A, Justén S et al. The effectiveness of two occupational health intervention programmes in reducing sickness absence among employees at risk. Two randomised controlled trials. Occup Environ Med 2008; 65: 236-41.

55. Taimela S, Justén S, Aronen P et al. An occupational health intervention programme for workers at high risk for sickness absence. Cost effectiveness analysis based on a randomised controlled trial. Occup Environ Med 2008; 65: 242-8.

56. Gravid og i arbeid. Et pilotprosjekt i regi av SørTroms HMS-tjeneste. Tromsø: Sør-Troms HMStjeneste, 2009.

57. Kristensen P, Nordhagen R, Wergeland E et al. Job adjustment and absence from work in mid-pregnancy in the Norwegian Mother and Child Cohort Study (MoBa). Occup Environ Med 2008; 65: 560-6.

Mottatt 11.06. 2010, første revisjon innsendt 06.10. 2010, godkjent 14.10. 2010.

Medisinsk redaktør Petter Gjersvik. 